\title{
ПРИЧИНИ СИНДРОМУ ХРОНІЧНОЇ ВТОМИ У СТУДЕНТІВ
}

\author{
Н. В. Богдан, О. I. Зарудна \\ Чемеровецький державний медичний коледж \\ Чемеровеџька центральна районна лікарня \\ ДВНЗ «Тернопільський державний медичний університет \\ імені І. Я. Горбачевського МОЗ України" \\ НнІ медсестринства
}

У статті проаналізовано причини синдрому хронічної втоми у студентів.

\section{COUSES OF THE CHRONIC FATIQUE SYNDROME IN STUDENTS}

\author{
N. V. Bohdan, O. I. Zarudna \\ Chemerivtsi State Medical College \\ Chemerivtsi Central District Hospital \\ I. Horbachevsky Ternopil State Medical University \\ Educational and Scientific Institute of Nursing
}

The article deals with causative factors of chronic fatique syndrome in students.

Вступ. У віці 17-25 років відбувається становлення цілісного інтелекту особистості і його окремих функцій, в чому визначальну роль відіграє освіта і навчання, тобто діяльність, пов'язана із засвоєнням знань, умінь і навичок. Фактор навчання, постійної розумової роботи утримує високий тонус інтелекту студентів, дозволяє їм ефективно виконувати напружену програму освіти.

Однак відновні процеси у багатьох студентів проходять неповноцінно з причини недостатнього сну, нерегулярного харчування, короткотривалого перебування на свіжому повітрі, обмеженого використання засобів фізичної культури і спорту, дезадаптації, розгублення тощо.

Іноді студентам складно призвичаїтись до навчання у вищому навчальному закладі, адже вчорашні школярі потрапляють в нові умови навчальної діяльності, нові життєві ситуації, що супроводжуються суттєвою перебудовою психічних і фізіологічних станів.

Основна частина. Вивчення бюджету часу студентів показує, що завантаження навчальною роботою, включно і самопідготовку, в різних навчальних закладах по факультетах і курсах у навчальному році далеко не однакова і визначається

(с) Н. В. Богдан, О. І. Зарудна, 2016 конкретними умовами, трудомісткістю і складністю досліджуваних дисциплін [1].

Час на навчальні заняття $є$ найбільш стабільним і складає 6-8 годин на день. Час на самопідготовку може вельми варіюватися і в середньому займає в день 3-5 годин, а в період сесій - 8-9. Таким чином, у середньому в сумі навчальна робота студентів становить 9-12 годин на день. За нашими спостереженнями та за даними інших дослідників - найбільш значні витрати часу на навчальну та самостійну роботу в першокурсників, що об'єктивно відображає їх адаптацію до стилю і методів навчання у навчальному закладі. Характерно, що значна частина студентів I курсу, які ще не навчилися правильно планувати свій час, займаються самопідготовкою по 2-4 години навіть у вихідні дні. Ці дані говорять про те, що навчальний процес студентів $є$ досить напруженим.

Вагомою $\epsilon$ кількість вільного часу студента. Він складає в середньому 1,7-2,8 години на день. Студенти присвячують його громадській роботі, оволодінню цінностями духовної культури, інтелектуальному і фізичному вдосконаленню, відпочинку. Умови, в яких живе, вчиться і відпочиває студент, справляють істотний вплив на його працездатність, стан здоров'я. А власне режим навчання, праці, прийому їжі, сну, 
оздоровчі заходи забезпечують економне витрачання нервової енергії та знижують нервово-психічну напруженість.

При опитуванні наших учнів було з'ясовано, що більшість студентів виконує домашні завдання пізно ввечері (21-23 год).

Робота в цей час вимагає підвищених витрат нервової енергії, що негативно позначається на якості сну, погіршує здоров'я, знижує ефективність засвоєння навчального матеріалу. У багатьох студентів порушений режим сну. В 87 \% студентів, які проживають в гуртожитку, відхід до сну затягується до 1-3 години ночі. Вкрай недостатня тривалість нічного сну до 6 годин спостерігається у 25 \% студентів, від 6-7 годин у $60 \%$. Нормальна тривалість сну від 7 до 8 годин відзначається лише в 15 \% студентів. При систематичному недосипанні спостерігається зниження розумової працездатності на 7-18\%. Недооціненим студентами залишається і режим харчування. У певні години споживають їжу близько 29 \% студентів, без сніданку йдуть на заняття - $21 \%$, не вечеряють - $16 \%$, близько 47 \% споживають гарячу їжу тільки 2 рази на день.

У період іспитів буквально «відлюдниками» стають близько 97 \% студентів, перебування на повітрі у них обмежується 30 хвилинами в день.

Дослідженнями встановлено, що добова динаміка працездатності людини багато в чому визначається періодикою фізіологічних процесів під впливом екзогенних (пов'язаних із зміною зовнішнього середовища); і ендогенних (ритм серця, дихання, стан кров'яного тиску, розумова і фізична активність, глибина сну та ін.) факторів. Ендогенні біологічні ритми називають біологічним годинником. Коливання працездатності протягом доби відповідають біологічній ритміці [1] .

Висока працездатність в будь-якому виді діяльності, як правило, забезпечується тільки в тому випадку, якщо життєвий ритм правильно узгоджується з властивими організму біологічними ритмами його психофізіологічних функцій. Так, до початку дня посилюється діяльність серцево-судинної системи, дихального апарату, тонус м'язової системи, збудливість нервової системи і т. д. І чим точніше збігається початок навчально-трудової діяльності з підвищенням тонусу життєво важливих функцій організму, тим продуктивніше виконується навчальний процес, підвищується витривалість організму, знижується стомлюваність, поліпшується самопочуття. Аналогії також можна провести і з відходом до сну [4].
Не завжди психофізіологічне піднесення збігається зі зростанням розумової діяльності. Це зумовлено, поперше, тим, що процес навчання характеризується постійним переходом на різні види розумової діяльності (лекції, семінари, лабораторні заняття та ін.), зміною обставин, по-друге, працездатність студентів пов'язана з їх особистими відмінностями, по-третє позначаються фактори, що визначаються організацією навчального процесу. Є студенти зі стійкою стереотипністю і послідовністю зміни працездатності та студенти з нестійкою їх послідовністю. Залежно від часу підвищення працездатності перші (близько 90 \% обстежуваних) підрозділяються на «ранкові» і «вечірні» типи. Студенти, віднесені до «ранкового» типу, так звані «жайворонки», встають рано, бадьорі, найбільш працездатні з 9-10 до 14 годин. Вони найбільш адаптовані до існуючого режиму навчання, їх біологічний ритм практично збігається з навчальним режимом денного навчального закладу. Студенти «вечірнього» типу або «сови», найбільш працездатні з 18-20 до 24 години. У першій половині дня їх працездатність знижена, вони пізно лягають спати, частіше не висипаються. Ці студенти (денної форми навчання) перебувають в менш сприятливих умовах навчання.

Робочий день студенти, як правило, не починають одразу з високою продуктивністю. На початку навчального дня вони не можуть одразу зосередитися і повністю включитися в заняття. На період пристосування йде від 10-20 до 40 хвилин, після чого настає стан «робочої установки» і працездатність поступово зростає, а потім знижується. У період відпочинку після занять спостерігається певне відновлення працездатності, рівень якого залежить від організації відпочинку.

Працездатність на початку навчального тижня буває надзвичайно знижена, що пов'язано з входженням у звичний режим навчальної роботи після відпочинку і вихідного дня. У середині тижня (вівторок-четвер) спостерігається найбільш високий рівень працездатності: у п'ятницю і суботу вона знижується.

На початку залікової сесії, коли на тлі триваючих навчальних занять студенти активно готуються до заліків та щоденне навантаження збільшується в середньому до 11-13 годин у поєднанні з емоційними переживаннями, працездатність починає знижуватися. У період іспитів ця тенденція посилюється. Під час зимових канікул працездатність повертається до 
вихідного рівня, а якщо відпочинок супроводжується активним використанням засобів фізичної культури і спорту, спостерігається явище повного відновлення працездатності. Початок другого півріччя також супроводжується періодом пристосування, однак тривалість його не перевищує 1,5 тижня.

Правильна організація розумової роботи і відпочинку - важлива умова для збереження здоров'я, працездатності й успішного оволодіння навчальними дисциплінами. Проблему режиму роботи і відпочинку не можна розглядати окремо, а лише в тандемі [1].

Характерним для студентів, які упродовж навчального року не відчувають хронічної втоми, $\epsilon$ те, що окремі ознаки такої втоми починають з'являтися всередині навчального року (наприклад, певне зростання фізіологічного та когнітивного дискомфорту), проте в кінці року вони зникають. У них можуть виявлятись ознаки комунікативно-мотиваційного дискомфорту, і це більше характеризуватиме студентів другого курсу та старших за віком.

Студенти, насамперед дівчата, які не відчувають втому впродовж навчального року, уникають фізичної активності. Важливо зазначити, що сфера фізичної активності не увійшла до фактора життєвих цінностей цієї групи студентів і має зворотні кореляції з індексом хронічної втоми та емоційним дискомфортом. Це означає, що менше залучення до фізичної активності, а це, власне, і характеризує цю групу студентів, сприятиме зростанню втоми і емоційного дискомфорту. Менша зацікавленість своєю майбутньою професією також призводитиме до зростання загальної втоми, погіршення загального самопочуття і когнітивному дискомфорту.

Вагоме місце для цієї групи студентів посідає цінність свого матеріального становища. що більше студенти прагнуть у своїй діяльності досягти такого рівня освіти, професійних навичок, сімейного добробуту, які 6 забезпечили їхні матеріальні потреби, то нижчим буде відчуття їхньої втоми, когнітивного та емоційного дискомфорту. Особистісні досягнення сприятимуть зниженню когнітивного дискомфорту та загальної втоми, а активна соціальна взаємодія $з$ іншими людьми і визнання цінностей сімейного життя сприятиме емоційному комфорту [2].

Російський фізіолог В. Віденський говорив: «втомлюються і знемагають не стільки від того, що багато працюють, а від того, що погано працюють», маючи на увазі погану організацію праці. Сформульовані ним загальні принципи або умови продуктивності роботи необхідно враховувати при організації навчального процесу, а саме:

1) у всяку трудову діяльність потрібно «входити» поступово, оскільки початок роботи збігається за часом з періодом пристосування до цієї роботи;

2) для високої працездатності необхідні дозування і ритм роботи. Поривчастість, форсоване напруження не забезпечують стійкої працездатності. Різним особам притаманний різний ритм роботи, однак можна «виховати» необхідний ритм у роботі. Такий ритм можна назвати щоденною роботою в одні й ті ж години при доцільному чергуванні її з перервами відпочинку. На початку для організації ритмічної роботи потрібно свідоме напруження волі. Як тільки студент у роботу втягнувся, примус знімається, виникає звичка, робота стає потребою. Якщо порядок в роботі, їі ритм встановлений правильно, студент з дня на день може працювати багато, не перевантажуючи себе;

3) наступна умова полягає у звичній послідовності й систематичності діяльності. Ця умова не визначає зміст роботи, який буде протягом семестру змінюватися, однак вона передбачає чітку фіксацію часу занять, їх характер, перерви на обід, вечерю, дорогу, активний відпочинок, культурні заходи, сон і т. д.;

4) має бути правильне чергування праці й відпочинку, а також зміни одних форм праці іншими. Правильне чергування розумової діяльності з регулярним і достатнім сном є одним із визначальних умов ії афективного виконання. Не менш важливо чергувати роботу і відпочинок протягом навчально-трудового дня. Відпочинок необхідний для збереження працездатності, щоб не допустити глибокого розвитку втоми. У цих умовах процеси відновлення перебігають ефективно. Якщо ж продовжувати роботу, не звертаючи уваги на почуття великої втоми, то згодом навіть тривалий відпочинок не завжди повною мірою відновить колишній рівень працездатності. Крім того, зміна предмету навчально-трудової діяльності також сприятливо позначається на ній. Ця умова знаходить відображення в чергуванні різних предметів у навчальному розкладі вузу; як наслідок, воно вимагає чергування різних за характером навчальних робіт при самопідготовці студентів - теоретичних, практичних, графічних робіт, читання;

5) систематичне (щоденне) виконання розумової навчальної роботи в одні й ті ж години доби (тренування, в результаті якої зміцнюється навичка, що дозволяє виконувати розумову діяльність продуктивніше і у великому обсязі). 
Висновки. Для навчальної праці студентів, незалежно від його часових параметрів (навчальний день, тиждень, семестри навчального року), зміни розумової працездатності характеризуються послідовною

\section{ЛІТЕРАТУРА}

1. Психофізіологічні основи навчання, праці та інтелектуальної діяльності [Електронний ресурс]. - Режим доступу : http://uadoc.zavantag.com/text/37221

2. Особливості сенсожиттєвих орієнтацій у студентів із вираженою хронічною втомою [Електронний ресурс]. Режим доступу : http://social-science.com.ua/article/570 зміною періодів пристосування, стійкою і високою працездатністю та періодом її зниження. Ця обставина має значення для розробки заходів щодо оптимізації умов навчально-трудової діяльності студентів.

3. Агаджанян Н. А. Адаптация и резервы организма / Н. А. Агаджанян. - М. : ФИС. - 1983. - 262 с.

4. Розенблат В. В. Проблема утомления / В. В. Розенблат. - М. : Медицина, 1975. - 240 с. 